\title{
ASSESSMENT OF SEED INFESTATION LEVEL OF BROWN SPOT (Bipolaris oryzae) IN DIFFERENT RICE GENOTYPES UNDER NATURAL EPIPHYTOTIC CONDITIONS
}

\author{
P. Pantha* and D.R. Yadav \\ National Rice Research Program, Hardinath, Dhanusha, Nepal \\ *Corresponding author's email: prakaspantha@gmail.com
}

\begin{abstract}
Bipolaris oryzae, the causal agent of brown spot disease, is an economically important pathogen of rice found in several rice growing countries in the world. Seed samples were collected from the rice experimental field comprised of different rice genotypes at National Rice Research Program, Hardinath, Dhanusha, Nepal in 2014 to determine the infestation level of B. oryzae and taxonomic identification of seed borne fungi by standard blotter method. The major recovered fungal mycoflora were B. oryzae, Pyricularia oryzae, Ustilaginoidea virens, Aspergillus flavus, Aspergillus niger, Curvularia oryzae, Rhizopus oryzae, Alternaria sp., Cercospora sp. and Penicillium sp. Seeds of all rice genotypes were infected with these fungi however frequency of fungal association varied among rice genotypes (from 12\% to 96\%). The percentage infection of B. oryzae was recorded maximum in all the rice genotypes compared to other seed-borne fungi. Madhaya dhan 845 and BI-05305-10-1-2 were the most infected genotypes and the infection percentage was $72 \%$ and $68 \%$, respectively. Similarly, the least infected genotypes were Sabitri and TN-1 and infection level of $8 \%$ was recorded in both genotypes. Our findings may be used to predict disease occurrence and fungal transfer to new uninfected areas. Moreover, this study suggests that rice seed should be properly detected to check contamination by pathogens before sowing for effective and healthy crop production.
\end{abstract}

Keywords: Bipolaris oryzae; infection level; mycoflora; rice genotypes

\section{Introduction}

Rice, the most important and prestigious food crop, occupies the first place in terms of area and production in Nepal (MoAD, 2014). Agriculture contributes 34\% to the gross domestic product (GDP) of Nepal while rice alone contributes nearly $17.21 \%$ to the agricultural gross domestic product and provides more than $50 \%$ of the total calorie requirement of the Nepalese people (MoAD, 2014). In Nepal, blast, brown leaf spot, sheath blight and bacterial leaf blight are the economically important diseases of rice (Dahal et al., 1992). Brown spot of rice caused by Bipolaris oryzae Subr. and Jain (Helminthosporium oryzae, Breda de Haan) has been reported to occur in all the rice growing countries (Khalili et al., 2012). Under low input management, water stress and direct seeded conditions, the disease is particularly important. The highest incidence of $B$. oryzae is found in rachilla followed by sterile lemma, palea, embryo and endosperm of rice kernels with typical brown spot (Sanchote and Van Ba, 2005). The conidiophores of $B$. oryzae are simple, septate, straight to flexuous, sometimes geniculate, pale-brown to olivebrown, lighter towards the apex bearing conidia at the end and on sides and are in solitary or in small groups (Mew and Gonzales, 2002). The infected seeds may fail to germinate, transmit disease to seedling and subsequently to growing plants (Fakir et al., 2002). Reduction of seed infestation through proper management in the field or through seed treatment is a good disease management process (Biswas and Ratan, 2008). There is meager information on diversity of mycoflora associated with seed of rice in Nepal. Thus, this study was conducted aiming with the assessment of mycoflora associated with rice seeds and their infection level.

\section{Materials and Methods}

\section{Selection of Genotypes}

Seeds of 20 promising rice genotypes originating from diverse sources were collected from National Rice Research Program of Nepal Agricultural Research Council, Hardinath, Dhanusha. These seeds were harvested from the genotypes that were exhibited natural epiphytotic conditions with high severity of brown spot during the year 2014. The samples were kept enclosed in paper bags with proper labeling and brought to the plant pathology 
laboratory of Agriculture and Forestry University (AFU) and kept in the refrigerator at $5 \pm 1^{\circ} \mathrm{C}$ for further studies.

\section{Plating of Seeds}

Seed samples of each genotype were assayed for the presence of fungi by standard blotter method following the protocol of International Seed Testing Association (ISTA, 2003). Three layers of blotting paper (Whatman No. 1) moistened with sterile water were placed at the bottom of 9$\mathrm{cm}$ diameter petri-plates. Four hundred seeds of each genotype were surface disinfected in $1 \%$ freshly prepared sodium hypochlorite solution for $2 \mathrm{~min}$. followed by rinsing twice with sterilized distilled water, air dried and then 25 sterilized seeds were plated onto moistened blotting paper in 1:8:16 fashion from the centre to periphery (Fig. 1). The plates were arranged in a completely randomized design with four replications (four plates/replication) and incubated in an incubator at $25 \pm 1^{\circ} \mathrm{C}$ under $12 / 12$ alternating cycles of near ultra-violet light and darkness. Watering was done regularly to keep the filter paper moist.

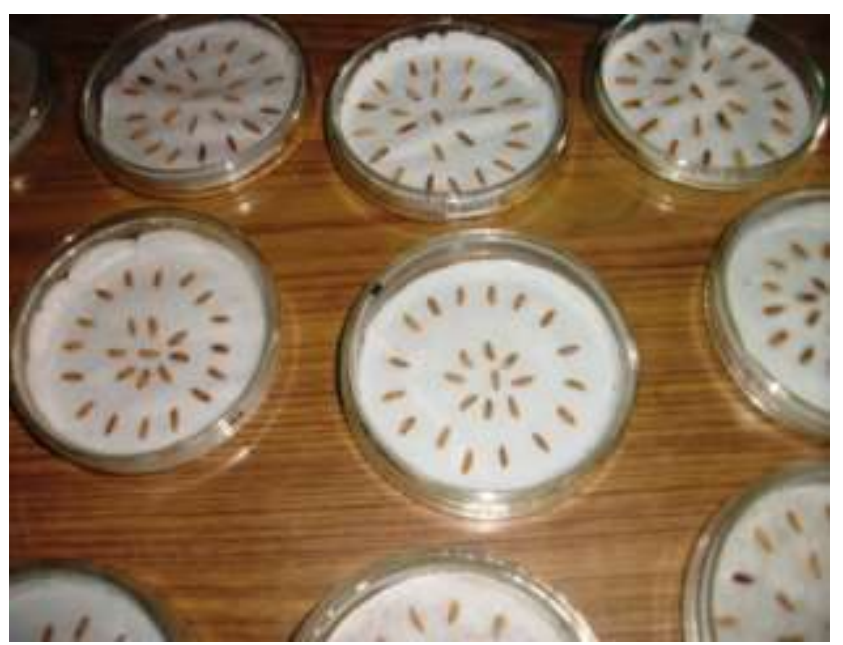

Fig 1: Arrangement of seeds on petri plates in $1: 8: 16$ fashion.

\section{Observations and Identification of Fungi}

All seeds of each replication were observed under stereomicroscope BS-80 (Boeco, Germany) after 3 days of incubation at $16 \mathrm{x}$ and $25 \mathrm{x}$ magnifications to detect seed borne fungi. The recovered fungal isolates were indentified on the basis of macro and micro morphological characteristics. Temporary slides were also prepared and observed under Olympus BX51 microscope (Tokyo, Japan) for accurate identification. The seeds were further observed at alternate dates up to 4 times and percentage of seed infection was calculated as below:

Seed infection $(\%)=\frac{\text { Number of infected seeds }}{\text { Total number of seeds observed }} \times 100$

\section{Data Analysis}

The recorded data were subjected for the analysis of variance and mean separation test was done using Duncan's multiple range tests (Gomez and Gomez, 1984). Statistical softwares, R 3.0.3 (R Core Team, 2013) and the agricolae version 1.1-8 package (De Mendiburu, 2014), were used for data analysis.

\section{Results and Discussion}

Major dominant mycoflora recovered from the collected seed samples were B. oryzae, Pyricularia oryzae, Ustilago inoidea virens, Aspergillus flavus, Aspergillus niger, Curvularia oryzae, Rhizopus oryzae, Alternaria sp., Cercospora sp. and Penicillium sp. Disease symptom on grain caused by $B$. oryzae and its morphological characteristics are shown in Fig. 2. Seeds of all the tested genotypes were found to be infected with fungi. However, the level of infection differed significantly $(\mathrm{p} \leq 0.001)$ (Table 1). The data on seed infection by $B$. oryzae and other fungi are tabulated in Table 2 . The seed infection was ranged from 12 to $96 \%$ and the highest seed borne fungal infection (96\%) was recorded in Sambha Mansuli and BI 0530-5-10-1-2 followed by Radha-12 (92\%), TCA 80-4 (90\%), IR05N449 (86\%), Sankharika (86\%), TOX 894-9-1 (84\%) and Basmati (82\%). The lowest infection percentage (12\%) was found in $\mathrm{TN}-1$. However, it was statistically at par with Hardinath-1 (15\%), Sabitri (16\%) and IR 81025-B-16-1 (18\%). The seed infection due to $B$. oryzae was $72 \%, 68 \%$, $12 \%$ and $8 \%$ in Madhaya dhan 845 , followed by BI 0530 5-10-1-2, Hardinath-1 and Sabitri, TN-1, respectively. The results revealed that all the tested genotypes were mostly infested with $B$. oryzae. Our results are in accordance with the finding of Habib et al., 2012 who also reported that $B$. oryzae is the dominant fungal pathogen in rice seeds. A significant correlation among the vertical spread of brown spot, head blight and black spot in seed and high mean maximum temperature $\left(31.77^{\circ} \mathrm{C}\right)$, relative humidity $(82.15 \%)$ and accumulated rainfall $(708.3 \mathrm{~mm})$ was reported by Singh and Siddiqui (Singh and Siddiqui, 2003). The viability of the pathogen is influenced by the seed storage temperature and relative humidity i.e. moderate temperature and high relative humidity (Dallagnol et al., 2011). Different pathogenic fungi like $B$. oryzae, Pyricularia oryzae, Rhizoctonia oryzae, Alternaria alternata, Alternaria padwickii, Alternaria longissima, Curvularia oryzae, Curvularia lunata, Aspergillus niger, Aspergillus flavus and species of Penicillium, Fusarium, Sclerotium, Colletotrichum were found to be associated with seeds (Gill and Khan., 2000; Wahid et al., 2002; Nguefack et al., 2007; Uma and Wesely, 2013; Dash, 2013). We also found the similar fungal diversity in our study. This is the first report of fungal diversity in the seeds of standing rice crop and the findings of the present study may be useful to design effective management of seed borne fungal diseases to check the transmission of fungal pathogens from seed to field. 
Table 1: Mean square value of seed infestation by Bipolaris oryzae and other fungi on 20 rice genotypes under natural epiphytotic conditions at Hardinath, Dhanusha, 2014.

\begin{tabular}{llll}
\hline \multirow{2}{*}{ Source of variations } & Degrees of freedom & \multicolumn{2}{c}{ Seed infestation } \\
\cline { 3 - 4 } & & Other fungi & B. oryzae \\
\hline Genotypes & 19 & $2342.4^{* * *}$ & $716.5^{* * * *}$ \\
Error & 60 & 195.8 & 11.5 \\
Total & 79 & & \\
\hline$* * *$ significant at $\mathrm{p} \leq 0.001$ & &
\end{tabular}
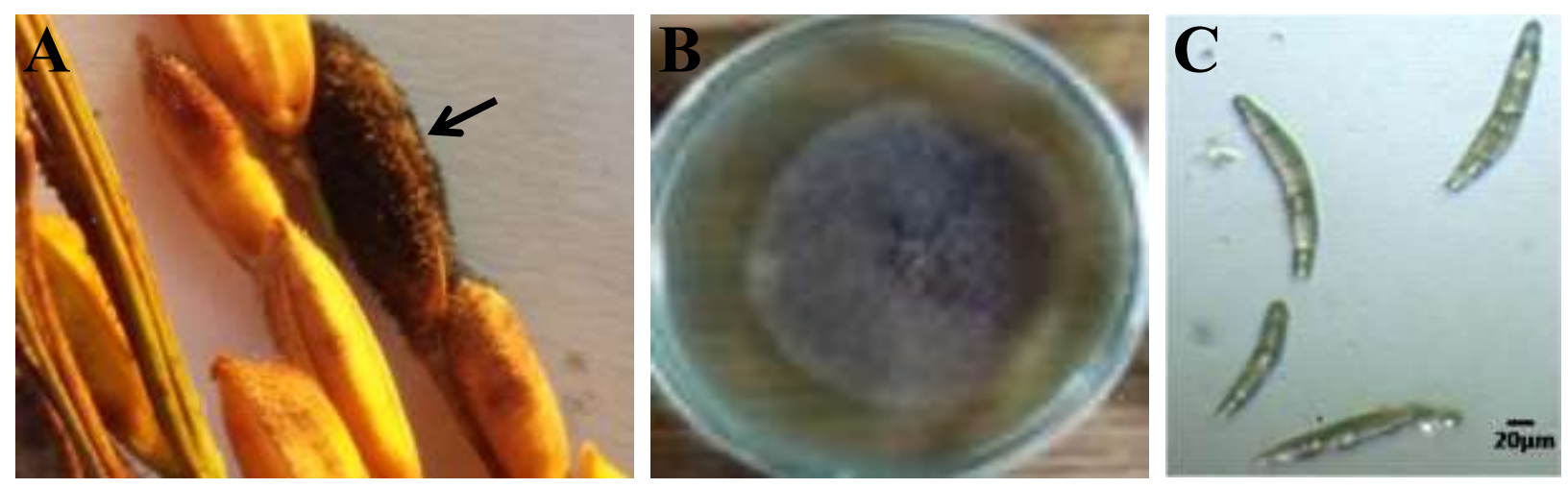

Fig 2: Seed infection, colony and morphological characters of Bipolaris oryzae. A, Black arrow indicates massive sporulation on grain in the field; $\mathrm{B}$, Colony on rice leaf extract agar media after 5 days of incubation at $25 \pm 1^{\circ} \mathrm{C} ; \mathrm{C}$, Conidia.

Table 2: Rice seed infection by different seed borne fungi and Bipolaris oryzae under natural epiphytotic conditions at Hardinath, Dhanusha, 2014.

\begin{tabular}{|c|c|c|}
\hline Genotypes & $\begin{array}{l}\text { Seed infection } \\
(\%)\end{array}$ & $\begin{array}{l}\text { Seed infection by Bipolaris oryzae } \\
(\%)\end{array}$ \\
\hline Sambha Mansuli & $96^{\mathrm{ab}}(76.07)$ & $64^{\mathrm{bc}}(39.17)$ \\
\hline BI 0530-5-10-1-2 & $96^{\mathrm{a}}(78.81)$ & $68^{\mathrm{ab}}(42.22)$ \\
\hline Radha-12 & $92^{\mathrm{a}-\mathrm{c}}(70.92)$ & $64^{\mathrm{bc}}(39.10)$ \\
\hline TCA $80-4$ & $90^{\mathrm{a}-\mathrm{d}}(67.89)$ & $48^{\mathrm{e}}(28.04)$ \\
\hline Sankharika & $86^{\mathrm{a}-\mathrm{d}}(63.53)$ & $56^{\mathrm{de}}(33.36)$ \\
\hline IR05N449 & $86^{\mathrm{a}-\mathrm{d}}(63.32)$ & $60^{\mathrm{cd}}(36.20)$ \\
\hline TOX 894-9-1 & $84^{\mathrm{a}-\mathrm{d}}(63.40)$ & $52^{\mathrm{e}}(30.69)$ \\
\hline Basmati (Rato) & $82^{\mathrm{a}-\mathrm{e}}(59.78)$ & $48^{\mathrm{e}}(28.69)$ \\
\hline IR 70213-10-CPAG-4-2-3-2 & $76^{\mathrm{b}-\mathrm{f}}(54.73)$ & $64^{\mathrm{bc}}(39.17)$ \\
\hline Madhaya dhan 845 & $75^{\mathrm{c}-\mathrm{g}}(49.87)$ & $72^{\mathrm{a}}(45.32)$ \\
\hline IR 73008-136-2-2-3 & $73^{\mathrm{d}-\mathrm{g}}(47.20)$ & $48^{\mathrm{e}}(28.04)$ \\
\hline Sona Mansuli & $62^{\mathrm{e}-\mathrm{g}}(39.20)$ & $52^{\mathrm{e}}(30.67)$ \\
\hline Makwanpur-1 & $60^{\mathrm{e}-\mathrm{g}}(37.42)$ & $36^{f}(21.10)$ \\
\hline NR 1893 & $58^{\mathrm{fg}}(36.66)$ & $32^{f}(18.69)$ \\
\hline Radha-11 & $51^{\mathrm{gh}}(31.20)$ & $52^{\mathrm{e}}(30.73)$ \\
\hline Radha-4 & $27^{\text {hi }}(15.68)$ & $16^{\mathrm{g}}(9.20)$ \\
\hline IR 81025-B-16-1 & $18^{\mathrm{i}}(10.36)$ & $12^{\mathrm{g}}(6.89)$ \\
\hline Sabitri & $16^{\mathrm{i}}(9.20)$ & $8^{g}(4.59)$ \\
\hline Hardinath-1 & $15^{\mathrm{i}}(8.64)$ & $12^{\mathrm{g}}(6.89)$ \\
\hline TN-1 & $12^{\mathrm{i}}(6.89)$ & $8^{g}(4.58)$ \\
\hline
\end{tabular}

Figures in the columns followed with alphabetic superscripts are significant at $\mathrm{p} \leq 0.001$ by Duncan's multiple range test; figures in the parentheses are the arcsine square root transformed values. 


\section{Conclusion}

The result of present study revealed that many seed borne pathogens are associated with rice seed. Of all fungi, $B$. oryzae was the most dominant pathogen infesting the seed of all rice genotypes with varied degree of infestation depending on the host genotypes. As seed is the unit of reproduction of flowering plant, pathogen free seed is the vital input in agriculture. In Nepal, much of rice seeds are imported from India and China so there is risk of introduction of seed-borne pathogens if proper quarantine lacks. Under suitable environmental conditions, they may create the disease in epidemic level. Detection of pathogen inoculum sources, prior to sowing, could prevent introduction of infected materials into fields, which could be useful in healthy growing of crop and for human consumption. Thus, control measures for reduction of primary inoculum should be adopted to minimize economic losses.

\section{Acknowledgement}

The authors would like to thank National Agricultural Research and Development Fund (NARDF), Kathmandu, Nepal for financial support to execute the study. We are very grateful to Agriculture and Forestry University (AFU), Rampur, Nepal to provide laboratory facilities.

\section{References}

Biswas SK and Ratan V (2008) Influence of seed treatment with biocides and foliar spray with fungicides for management of brown leaf spot and sheath blight of paddy. Indian Phytopathology. 61(1): 55-59.

Dahal G, Amatya P and Manandhar HK (1992) Bibliographic database on plant pathology in Nepal. Journal of Institute of Agriculture and Animal Science. 13: 53-64. http://dx.doi.org/

Dallagnol LJ, Rodrigues FA and Da Matta FM (2011) Brown spot of rice as affected by phyton irradiance and temperature. J. Phytopathol. 159: 630-634. DOI: $10.1111 /$ j.1439-0434.2011.01819.x

Dash C (2013) Seed health and quality test of three rice varieties for the detection of fungi associated with seed sample. Universal Journal of Plant Science. 1(2): 37-42.

De Mendiburu F (2014) Agricolae: statistical procedures for agricultural research. $R$ package version. 1: 1-6.

Fakir GA, Hossain I Ahmad MU Doula MAU and Alam MM (2002) Quality of farmer's boro and T. aman rice seeds collected before sowing from Bogra, Rajshahi and Rangpur district of Bangladesh. In Proceedings of the 2002 Planning Meeting of the Rice Seed Health Improvement Sub-Project.
Gill MA and Khan MG (2000) Seed borne fungi of rice from central Punjab and their control. Pakistan Journal of Phytopathology. 12(1): 12-14.

Gomez KA and Gomez AA (1984) Statistical procedures for agricultural research. John Wiley and Sons.

Habib A, Javed N Sahi ST and Waheed M (2012) Detection of seed-borne mycoflora of different coarse and fine rice varieties and their management through seed treatment. Pakistan Journal of Phytopathology. 24(2): 133-136.

ISTA (2003) International rules for seed testing, rules 2003 (Draper, S.R., Eds.) Zurich, Switzerland, ISTA.

Khalili E, Sadravi M Naeimi S and Khosravi V (2012) Biological control of rice brown spot with native isolates of three Trichoderma species. Brazilian Journal of Microbiology. 43(1): 297-305. DOI: 10.1590/S1517-83822012000100035

Mew TW and Gonzales (2002) A handbook of rice seedborne fungi. International rice research institute, Los Banos, Phillipines, 83.

MoAD (2014) Statistical information on Nepalese agriculture. Government of Nepal, Ministry of agricultural development, agri-business promotion and statistics division, Singha Durbar, Kathmandu, Nepal.

Nguefack J, Nguikwie SK Fotio D Dongmo B Zollo PA Leth V ... and Poll L (2007) Fungicidal potential of essential oils and fractions from Cymbopogon citratus, Ocimum gratissimum and Thymus vulgaris to control Alternaria padwickii and Bipolaris oryzae, two seed-borne fungi of rice (Oryza Sativa L.). Journal of Essential Oil Research. 19(6): 581587. DOI: 10412905.2007 .9699336

Sanchote S and Van Ba V (2005) Seed borne and transmission of Bipolaris oryzae, the causal pathogen of brown spot of rice. In Proceedings of 43rd Kasetsart University Annual Conference, Thailand, 1-4 February, 2005. Subject: Plants. (pp. 163-172). Kasetsart University.

Singh LP and Siddiqui ZA (2003) Effects of fly ash and Helminthosporium oryzae on growth and yield of three cultivars of rice. Bio resource technology. 86(1): 73-78. DOI: 10.1016/S0960-8524(02)001116

Uma V and Wesely EG (2013) Seed-borne fungi of rice from South Tamil Nadu. Journal of Academia and Industrial Research. 1: 612-614.

Wahid SA, Javed MS Idrees M Gill MA Khan SM and Javed N (2002) Studies on the association and effect of Fusarium solani on rice seeds in Punjab, Pakistan. In Integrated plant disease management. Proceedings of 3rd National Conference of Plant Pathology, NARC, Islamabad, 1-3 Oct. 2001. (pp. 70-72). Pakistan Phytopathology Society. 